\title{
Trends in restorative composites research: what is in the future?
}

\section{Mariel Soeiro MAAS(a) \\ Yvette ALANIA ${ }^{(a)}$ \\ Livia Camargo NATALE(a) \\ Marcela Charantola RODRIGUES(a) \\ David Christopher WATTS(b) \\ Roberto Ruggiero BRAGA ${ }^{(a)}$}

(a) Universidade de São Paulo - USP, School of Dentistry, Department of Biomaterials and Oral Biology, São Paulo, SP, Brazil.

(b) University of Manchester School of Medical Sciences, Division of Dentistry, Manchester, United Kingdom.
Declaration of Interests: The authors certify that they have no commercial or associative interest that represents a conflict of interest in connection with the manuscript.

\section{Corresponding Author:}

Roberto Ruggiero Braga

E-mail: rrbraga@usp.br

https://doi.org/10.1590/1807-3107BOR-2017.vol31.0055

Submitted: May 11, 2017

Accepted for publication: May 22, 2017

Last revision: May 23, 2017

\begin{abstract}
Clinical trials have identified secondary caries and bulk fracture as the main causes for composite restoration failure. As a measure to avoid frequent reinterventions for restoration replacement, composites with some sort of defense mechanism against biofilm formation and demineralization, as well as materials with lower susceptibility to crack propagation are necessary. Also, the restorative procedure with composites are very time-consuming and technically demanding, particularly concerning the application of the adhesive system. Therefore, together with bulk-fill composites, self-adhesive restorative composites could reduce operator error and chairside time. This literature review describes the current stage of development of remineralizing, antibacterial and self-healing composites. Also, an overview of the research on fiber-reinforced composites and self-adhesive composites, both introduced for clinical use in recent years, is presented.
\end{abstract}

Keywords: Composite Resins; Calcium Phosphates; Anti-Bacterial Agents; Adhesives

\section{Introduction}

As resin composites approach a half century of clinical use, it is possible to identify their "developmental cycles" motivated by deficiencies observed in the clinic. In the first two decades (1980's and 1990's), the focus was on filler systems that would allow for materials with superior mechanical properties, wear resistance and good polishing, resulting in the development of microhybrid composites. ${ }^{1}$ From the mid-1990's to mid-2000's, efforts were directed towards reducing polymerization shrinkage as an strategy to reduce post-operative sensitivity, cuspal deflection, and interfacial gap formation. ${ }^{2}$ In this decade, bulk-fill composites are becoming increasingly popular due to the clinical appeal of reducing the time necessary to insert the composite into the cavity preparation. ${ }^{3}$

While the use of restorative resin composites becomes more and more ubiquitous and indication boundaries are extended, their service time is usually abbreviated by the development of new caries lesions at the tooth-restoration interface ("secondary caries") or by fracture of the material. ${ }^{4,5}$ Such occurrences are not necessarily related to a material deficiency. The skill level of the professional and the patient's awareness regarding good dietary and oral hygiene habits seem to be determinative for restoration success. ${ }^{6,7}$ Still, the accumulated clinical experience suggests 
that improvements in composite fracture toughness (i.e., resistance to crack propagation), as well as the incorporation of protective mechanisms to reduce the risk of caries development are necessary to increase the restoration's longevity.

The aim of this review is to present to the reader some of the technologies recently made available for clinical use and to describe some of the current research efforts that, if translated to the clinical practice, may allow for composite restorations with extended service life. The topics discussed can be divided into three main strategy groups: 1) simplification of the restorative procedure (self-adhesive composites); 2) strategies to reduce the risk of composite bulk fracture (fiber-reinforced and self-healing composites); 3) defense mechanisms against new caries lesions at the tooth-restoration interface (remineralizing and antibacterial agents).

\section{Strategy 1: Self-adhesive restorative composites}

Self-adhesive restorative composites (SACs) were introduced in the dental market in 2009 and, currently, there are three examples available for clinical use (Table 1). These low-viscosity materials are indicated for small class I cavities and non-carious cervical lesions. ${ }^{8}$ Unfortunately, reports of in vitro evaluations of these materials are scarce and clinical studies are almost non-existent.

A key difference between SACs and self-adhesive resin cements (SARCs) is that SACs do not undergo acid-base neutralization reactions nor contain fluoride-releasing glass fillers..$^{10}$ In fact, SACs are more akin to self-etch adhesive systems due to the presence of acidic monomers such as glycerol phosphate dimethacrylates (GPDM), carboxylic methacrylates (for example, 4-MET) or phosphate ethyl methacrylates (BMEP). These monomers vary in acidity from mild (for example, GPDM with a $\mathrm{pH}=1.9$ ) to ultra-mild (4-MET, $\mathrm{pH}=3-4)^{11}$ and are responsible for partially etching the tooth substrate and penetrating through the smear layer, forming a submicron-thick hybrid layer. ${ }^{12}$ Hydroxyethyl methacrylate (HEMA) is added to increase the wettability of the material on the dentin surface. ${ }^{13}$

Similar to self-adhesive resin cements, though, is the fact that SAC interaction with dentin is limited by the extent of decalcification produced by the acidic monomers. Furthermore, their relatively high viscosity as the result of filler incorporation makes wetting of the bonding substrate even more difficult, ${ }^{12,14,15}$ limiting the diffusion of monomers into the collagen fibers network. ${ }^{16}$ Notwithstanding, some chemical interaction with calcium from hydroxyapatite has been verified, suggesting that the retention relies not only on micro-mechanical interlocking. ${ }^{17,18}$

Overall, studies agree that SACs exhibit lower bond strength values to dental tissues than conventional restorative systems (Table 2), ${ }^{12,19,20,21,22,23,24}$ with a few exceptions where composites were tested on radicular dentin ${ }^{25,26}$ Several studies suggest that pre-etching enamel and dentin with phosphoric acid significantly increases bond strength, as phosphoric acid removes the smear layer and enhances surface area. ${ }^{8,9,19,27,28,29}$ Using a self-etch adhesive prior to the application of Vertise Flow significantly increased

Table 1. Composition of commercially available self-adhesive composites.

\begin{tabular}{|c|c|c|}
\hline Material & Manufacturer & Composition \\
\hline \multirow[t]{2}{*}{ Fusio Liquid Dentin* } & \multirow{2}{*}{$\begin{array}{l}\text { Pentron Clinical, } \\
\text { Orange, CA, USA }\end{array}$} & $\begin{array}{l}\text { Resin: aliphatic diurethane dimethacrylate (UEDMA), triethylene glycol dimethacrylate (TEGDMA), } \\
\text { hydroxyethyl methacrylate (HEMA), trimelitic acid methacrylate (4-MET), catalyst }\end{array}$ \\
\hline & & Fillers: $\mathrm{SiO}_{2}(65 \mathrm{w}+\%)$, silanated barium glass, $\mathrm{NaF}$ \\
\hline \multirow[t]{2}{*}{ Vertise Flow* } & \multirow{2}{*}{$\begin{array}{l}\text { Kerr, Orange, CA, } \\
\text { USA }\end{array}$} & $\begin{array}{l}\text { Resin: glycerolphosphoric acid dimethacrylate (GPDMA), HEMA, bisphenol glycidil dimethacrylate } \\
\text { (Bis-GMA), catalysts }\end{array}$ \\
\hline & & Fillers: pre-polymerized filler, silanated barium glass, nano-sized colloidal $\mathrm{SiO}_{2}, \mathrm{YF}_{3}(70$ wt\%) \\
\hline \multirow[t]{2}{*}{ Embrace Wetbond** } & \multirow{2}{*}{$\begin{array}{c}\text { Pulpdent, } \\
\text { Watertown, MA, } \\
\text { USA }\end{array}$} & $\begin{array}{c}\text { Resin: aliphatic diurethane dimethacrylate (UEDMA), bis-methacryloyloxy ethyl phosphate (BMEP), } \\
\text { trimethyloyl propane trimethacrylate (TMPTMA), HEMA, water, catalysts }\end{array}$ \\
\hline & & Fillers: $\mathrm{SiO}_{2}, \mathrm{NaF}(37 \mathrm{wt} \%)$ \\
\hline
\end{tabular}

*from Reference $9 ;{ }^{* *}$ manufacturer information. 
Table 2. Bond strength studies.

\begin{tabular}{|c|c|c|c|c|c|}
\hline Reference & $\begin{array}{l}\text { Bonding } \\
\text { substrate }\end{array}$ & $\begin{array}{l}\text { Testing } \\
\text { method }\end{array}$ & $\begin{array}{l}\text { Self-adhesive } \\
\text { composite }\end{array}$ & Control group & Outcome \\
\hline \multirow{2}{*}{$\begin{array}{l}\text { Giachetti et al. } \\
(2012)^{25}\end{array}$} & \multirow{2}{*}{$\begin{array}{l}\text { radicular } \\
\text { dentin }\end{array}$} & \multirow{2}{*}{ Push-out } & \multirow{2}{*}{ Vertise flow } & \multirow{2}{*}{$\begin{array}{l}\text { etch-and-rinse adhesive } \\
\quad+\text { resin cement }\end{array}$} & SAC: 21.6-23.2 MPa \\
\hline & & & & & Control: 20.4-24.7 MPa \\
\hline \multirow{2}{*}{$\begin{array}{l}\text { Mobarak and } \\
\text { Seyam }(2013)^{26}\end{array}$} & \multirow{2}{*}{$\begin{array}{l}\text { radicular } \\
\text { dentin }\end{array}$} & \multirow[b]{2}{*}{ Push-out } & \multirow[b]{2}{*}{ Vertise flow } & \multirow{2}{*}{$\begin{array}{l}\text { etch-and-rinse adhesive }+ \\
\text { resin cement or dual cure } \\
\text { self-etch resin cement }\end{array}$} & SAC: 18.0-19.1 MPa \\
\hline & & & & & Control: 11.3-14.4 MPa \\
\hline \multirow{4}{*}{$\begin{array}{l}\text { Vichi et al. } \\
(2013)^{12}\end{array}$} & \multirow{4}{*}{ enamel/dentin } & \multirow{4}{*}{ Shear } & \multirow{4}{*}{ Vertise flow } & \multirow{4}{*}{$\begin{array}{l}\text { self-etch adhesive }+ \\
\text { flowable composite }\end{array}$} & Enamel: \\
\hline & & & & & SAC: $2.6 \pm 2.6 \mathrm{MPa}$; Control: 5.0-12.1 MPa \\
\hline & & & & & Dentin: \\
\hline & & & & & SAC: $3.4 \pm 1.6 \mathrm{MPa}$; Control: 5.8-12.2 MPa \\
\hline \multirow{10}{*}{$\begin{array}{l}\text { Poitevin et al. } \\
(2013)^{19}\end{array}$} & \multirow{10}{*}{ enamel/dentin } & \multirow{10}{*}{ Micro-tensile } & \multirow{10}{*}{$\begin{array}{l}\text { Vertise flow } \\
\text { Fusio liquid } \\
\text { dentin }\end{array}$} & \multirow{10}{*}{$\begin{array}{l}\text { self-etch adhesive }+ \\
\text { flowable composite }\end{array}$} & SAC (enamel): \\
\hline & & & & & Vertise flow: $11.0 \pm 4.2 \mathrm{MPa}$ \\
\hline & & & & & Vertise flow with previous etching: $23.1 \pm 7.1 \mathrm{MPa}$ \\
\hline & & & & & Fusio liquid dentin: $13.0 \pm 4.3 \mathrm{MPa}$ \\
\hline & & & & & Control (enamel): $28.0 \pm 9.8 \mathrm{MPa}$ \\
\hline & & & & & SAC (dentin): \\
\hline & & & & & Vertise flow: $1.8 \pm 2.7 \mathrm{MPa}$ \\
\hline & & & & & Vertise flow with previous etching: $18.7 \pm 11.0 \mathrm{MPa}$ \\
\hline & & & & & Fusio liquid dentin: $17.7 \pm 8.6 \mathrm{MPa}$ \\
\hline & & & & & Control (dentin): 7.9-44.8 MPa \\
\hline \multirow{4}{*}{$\begin{array}{l}\text { Goracci et al. } \\
(2013)^{9}\end{array}$} & \multirow{4}{*}{ enamel } & \multirow{4}{*}{ Shear } & \multirow{4}{*}{ Vertise flow } & \multirow{4}{*}{$\begin{array}{c}\text { etch-and-rinse or self-etch } \\
\text { adhesive }+ \text { orthodontic } \\
\text { cement }\end{array}$} & SAC: \\
\hline & & & & & Vertise flow: $3.0 \pm 1.2 \mathrm{MPa}$ \\
\hline & & & & & Vertise flow with previous etching: $6.6 \pm 1.1 \mathrm{MPa}$ \\
\hline & & & & & Control: 9.0-11.7 MPa \\
\hline & & & & & SAC: \\
\hline Fu et al. & dentin & Micre tencile & Vertise flow & self-etch primer adhesive & Vertise flow: $13.0 \pm 9.9 \mathrm{MPa}$ \\
\hline$(2013)^{24}$ & dentin & Micro-fensile & $\begin{array}{l}\text { rusio liquid } \\
\text { dentin }\end{array}$ & system + resin composite & Fusio Liquid Dentin: $25.2 \pm 6.1 \mathrm{MPa}$ \\
\hline & & & & & Control: $79 \pm 16.1 \mathrm{MPa}$ \\
\hline & & & & & SAC (primary dentin): \\
\hline & & & & & Vertise flow: $4.1 \pm 2.3 \mathrm{MPa}$ \\
\hline & & & & & $\begin{array}{l}\text { Vertise flow with previous self-etch adhesive: } \\
\qquad 8.7 \pm 1.7 \mathrm{MPa}\end{array}$ \\
\hline Tuloglu et al. & primary and & Chore & Votic flow & self-etch adhesive + & Control (primary dentin): $15.6 \pm 2.6 \mathrm{MPa}$ \\
\hline$(2014)^{21}$ & $\begin{array}{l}\text { permanent } \\
\text { dentin }\end{array}$ & snear & vertise flow & flowable composite & SAC (permanent dentin): \\
\hline & & & & & Vertise flow: $19.3 \pm 2.3 \mathrm{MPa}$ \\
\hline & & & & & $\begin{array}{l}\text { Vertise flow with previous self-etch adhesive: } \\
\qquad 25.6 \pm 3.0 \mathrm{MPa}\end{array}$ \\
\hline & & & & & Control (permanent dentin): $35.7 \pm 2.9 \mathrm{MPa}$ \\
\hline & & & & & SAC: \\
\hline Makishi et al. & dentin & Shear & Vertise flow & etch-and-rinse adhesive & Vertise flow: $13.9 \pm 3.6 \mathrm{MPa}$ \\
\hline$(2015)^{22}$ & dentin & snear & $\begin{array}{l}\text { rusio liquid } \\
\text { dentin }\end{array}$ & + resin composite & Fusio liquid dentin: $11.3 \pm 3.2 \mathrm{MPa}$ \\
\hline & & & & & Control: $27.3 \pm 6.1 \mathrm{MPa}$ \\
\hline & & & & & SAC: \\
\hline Sachdeva et al. & & & Vertise flow & conventional flowable & Vertise flow: $12.0 \pm 3.1 \mathrm{MPa}$ \\
\hline$(2016)^{23}$ & primary dentin & Shear & $\begin{array}{l}\text { Fusio liquid } \\
\text { dentin }\end{array}$ & composite & Fusio liquid dentin: $14.2 \pm 4.1 \mathrm{MPa}$ \\
\hline & & & & & Control: $21.1 \pm 3.8 \mathrm{MPa}$ \\
\hline
\end{tabular}


the dentin bond strength and reduced microleakage scores, when compared with the application of the SAC alone. ${ }^{21}$ Obviously, adding an extra step to the restorative procedure with self-adhesive composites defeats the purpose of simplifying the procedure. Interestingly, despite their low bond strength, Vertise Flow showed better marginal sealing ability in comparison with self-adhesive and etch-and-rinse adhesive systems possibly due to hygroscopic expansion and a relatively low polymerization stress development at the bonded interface. ${ }^{12,14,23}$ Another evidence of the limited adhesion of these materials to tooth structure was the retention rate of only 33\% displayed by Fusio liquid dentin in non-carious cervical lesions after a six-month clinical evaluation, in comparison to the $100 \%$ retention of a conventional restorative composite. ${ }^{30}$

The physical properties of SACs have not been thoroughly evaluated. In one study, Vertise Flow showed flexural strength similar to conventional (i.e., non-self-adhesive) flowable composites. ${ }^{31}$ After toothbrushing abrasion, Vertise flow had a rougher surface compared to that resulting from the application of Fusio liquid dentin and a conventional restorative composite. ${ }^{32}$ Results can be related to the type of organic matrix, since urethane-based composites have a better wear resistance than Bis-GMA-based composites, other factors being equal. ${ }^{33}$ SACs also showed a much poorer performance in terms of gloss retention than a conventional control. ${ }^{32}$ Self-adhesive composites are more hydrophilic than conventional composites due to the presence of acidic monomers and HEMA. In fact, Vertise Flow showed much higher hygroscopic expansion ${ }^{34}$ and higher water sorption ${ }^{35}$ when compared with conventional composites after 150 days in water. A drawback indeed, since SACs hydrophilicity may facilitate network plasticization, enhance biofilm formation and increase degradation. ${ }^{28,34}$

The idea of bonding the composite directly to the tooth structure is enticing. However, based on the limited amount of information available, it seems that self-adhesive restorative composites are still at their inception and more research is necessary to solve the limitations found with the current materials.

\section{Strategy 2A: Fiber-reinforced composites}

Current restorative composites present fracture toughness $\left(\mathrm{K}_{\mathrm{Ic}}\right)$ values varying between 0.9 to 1.8 MPa.m ${ }^{0,5}, 1$ which seems insufficient to avoid clinical failures by bulk fracture. ${ }^{4,5}$ The incorporation of small fractions of short, random glass fibers as part of the filler system is one of the strategies currently in use to create tougher composites.

The use of glass fibers as reinforcement in dental composites is not new. The use of randomlyoriented low aspect ratio (AR: length-to-diameter ratio) glass fibers as reinforcing phase in composites was published in $1989^{36}$ and in the 1990s composites containing low AR fibers (20-120 $\mu \mathrm{m}$ in length, $6 \mu \mathrm{m}$ in diameter) associated with filler particles appeared in the market (Restolux, Lee Pharmaceutical, South El Monte, CA, USA, and ALERT, Pentron, Orange, CA, USA). In fact, studies showed higher $\mathrm{K}_{\mathrm{Ic}}$ values for ALERT compared to other packable and regular consistency materials, but no difference in flexural strength was observed. ${ }^{37,38}$

Recently, a bulk-fill composite containing high AR E-glass fibers (1-2 $\mathrm{mm}$ in length, $17 \mu \mathrm{m}$ in diameter) was released (EverX Posterior, GC Europe, formerly known as Xenius Base). Its total mass filler fraction is $74.2 \mathrm{wt} \%$ (53.6 vol\%), with $8.6 \mathrm{wt} \%$ (7.2 vol\%) of glass fibers. ${ }^{39}$ Its resin matrix is constituted by BisGMA, TEGDMA and PMMA (polymethyl methacrylate), forming a semi-interpenetrating polymer network (semi-IPN). ${ }^{40}$ As fibers impair polishing, it is indicated as a substructure material and a final layer of particulate composite is mandatory. Overall, its fracture strength does not seem to differ from those of particle-only composites. ${ }^{20,41}$ Fatigue strength of teeth restored with this material also did not differ from that of a conventional composite. ${ }^{42}$ The only report on the material's $\mathrm{K}_{\mathrm{Ic}}$ showed a significantly higher value, compared to other commercial composites. ${ }^{43}$

In order to understand the effect of fibers on composite properties, it is important to look at the variables involved in fiber reinforcement using systematic experimental designs. Two important parameters related to composite reinforcement using random, short fibers are the fiber AR and volume fraction. An effective stress transfer from the matrix to the fiber requires fibers with a minimum length 
("critical length"), estimated from the fiber strength and diameter (therefore, related to fiber AR) and on the interfacial bond strength between the fiber and the matrix. ${ }^{44}$ For example, the addition of $20 \mathrm{vol} \%$ high AR fibers $(A R=68)$ to a commercial flowable composite (filler fraction: $43.6 \mathrm{vol} \%$ ) had a positive effect on flexural strength compared to low AR fibers ( $\mathrm{AR}=5.2){ }^{45}$

The replacement of up to $7.5 \mathrm{vol} \%$ of particles by fibers $(A R=140)$ did not increase the flexural strength of experimental composites containing $60 \mathrm{vol} \%$ of fillers. Though randomly oriented fibers are supposed to result in a material with isotropic behavior, it is possible that the insertion of the composite into the mold during specimen preparation results in some fiber orientation perpendicular to load application, which reduces reinforcement efficiency. ${ }^{46}$

On the other hand, studies agree that fibercontaining commercial composites present higher $\mathrm{K}_{\mathrm{Ic}}$ than particle-only composites. ${ }^{37,38,39,43,47} \mathrm{In}$ fact, the replacement of $5 \mathrm{vol} \%$ of glass particles by fibers in a composite with $60 \mathrm{vol} \%$ of fillers resulted in a two-fold increase in $\mathrm{K}_{\mathrm{Ic}}$ (from 1.25 to $2.6 \mathrm{MPa}^{1 / 2}{ }^{1 / 2}$. ${ }^{46}$ The presence of fibers increases "crack bridging", i.e., when a crack propagates through the material, fibers pull the crack faces together and, as a result, more energy is necessary for the crack to propagate further. ${ }^{48}$

Besides increasing $\mathrm{K}_{\mathrm{Ic}}$ fibers may also interfere with composite polymerization shrinkage. Composites containing continuous, oriented fibers present anisotropic behavior in terms of shrinkage, with lower values being registered in the direction of the fibers in comparison to the perpendicular direction. ${ }^{43,49}$ On the other hand, composites containing short random fibers are expected to show isotropic behavior. However, depending on the specimen configuration and testing method, fiber-containing composites may show lower shrinkage than particle-only composites. For example, Xenius base showed 43-51\% lower post-gel shrinkage in comparison to composites with higher filler fractions when tested by the strain gage method. ${ }^{43}$ Also using the strain gage method, an inverse relationship between fiber content and post-gel shrinkage was observed when $2.5 \mathrm{vol} \%$ to $7.5 \mathrm{vol} \%$ of the filler particles were replaced by $1.4 \mathrm{~mm}$ glass fibers in a $60 \mathrm{vol} \%$ filler experimental composite, with shrinkage reductions reaching $70 \%$ at the highest fiber content. ${ }^{46}$ Strain gages record mostly the shrinkage taking place adjacently to the sensor grid and during specimen preparation, some degree of fiber orientation may result from pressing the composite against it. Consequently, the material does not behave as totally isotropic. When using the mercury dilatometer, a composite containing $6 \mathrm{vol} \%$ of fibers and $54 \mathrm{vol} \%$ particles showed a much subtler reduction in total shrinkage $(11 \%)$ in comparison to the $60 \mathrm{vol} \%$ particle-only composite. As polymerization stress development is the result of complex interactions between composite elastic modulus, shrinkage and testing system compliance, such difference in shrinkage was not enough to reduce stress magnitude. ${ }^{46}$ Other studies showed that EverX Posterior developed either similar or higher polymerization stress and gap formation in vitro compared to other bulk-fill materials. ${ }^{3,50}$

\section{Strategy 2B: Self-healing composites}

Failure mechanism in polymers can be described as the result of damage accumulation, where microcracks propagate due to thermal or mechanical stress concentration at the crack tip. ${ }^{51}$ Therefore, bringing crack extension to a halt by sealing the crack faces ("crack healing") may increase composite life-span. The development of self-healing polymers was a major breakthrough in polymer chemistry. According to Huyang et al. ${ }^{52}$ "self-healing mechanisms are biomimetic models of autonomic repair systems in living tissues that efficiently handle damage, for example, the healing of a broken bone". The "proof of concept" for this approach was published by Dry. ${ }^{53}$ In a series of experiments, she used hollow glass fibers filled with either a two-part epoxy system or a cyanoacrylate adhesive embedded in epoxy specimens to demonstrate the material's self-healing ability. Besides recovering part of the initial strength after fracture, the self-repair system was shown to arrest microcracks and prevent crack reopening.

Research in dental composites self-repair systems derives from the approach introduced by White et al. ${ }^{54}$ They synthesized dicyclopentadiene (DCPD) -filled microcapsules (50-200 $\mu \mathrm{m})$ with a urea-formaldehyde (UF) shell and dispersed them an epoxy matrix. When the crack front reached a microcapsule, its shell was 
ruptured and DCPD was released within the crack plane by capillarity. Polymerization of the healing agent was triggered by contact with a transition metal catalyst (Grubbs' catalyst) incorporated in the matrix. A healing efficiency of $60 \%$ was reported in notched specimens containing $10 \mathrm{wt} \%$ of microcapsules and $2.5 \mathrm{wt} \%$ of catalyst, monotonically loaded to failure in mode I (i.e., perpendicular to the precrack) and re-tested after being allowed to heal for 48 hours. In a subsequent development, they tested microcapsules filled with an epoxy-solvent mixture. ${ }^{55}$ In this case, healing occurs by swelling of the set epoxy and transport of the residual amine to the crack plane. The additional epoxy released from the microcapsule increases the chance of crack healing by crosslinking. After a first healing event with a $100 \%$ efficiency (i.e., full recovery of the initial $\mathrm{K}_{1 \mathrm{c}}$ ), a maximum of five healing events were verified, with decreasing efficiency due to the depletion of healing agent, as well as the available amine.

Fatigue loading represents a more clinically relevant scenario for testing polymer self-repair than static conditions. It has been verified that under cyclic loading healing efficiency is related to crack growth rate (defined by stress amplitude and frequency), the polymerization rate of the healing agent and the occurrence of rest periods. For example, in an epoxy resin containing $20 \mathrm{wt} \%$ of DCPD-filled UF microcapsules, if stress intensity is such that crack extension occurs at a similar rate of that of healing agent curing, the fatigue life extension ranged from $89 \%$ to $213 \% .^{56}$

The first attempt to formulate a self-healing dental composite used the DCPD-filled UF microcapsules developed by White et al. ${ }^{54}$ Specimens made of a BisGMA/UDMA/TEGDMA resin containing $55 \mathrm{wt} \%$ of silanated silica, $5 \mathrm{wt} \%$ microcapsules (average size: $50 \mu \mathrm{m})$ and $2 \mathrm{wt} \%$ of Grubbs' catalyst were tested for $\mathrm{K}_{1 \mathrm{c}}$ and re-tested after a 7-day healing period at room temperature, with average healing efficiency of $57 \% .{ }^{57}$ It should be noted that the presence of the capsules within the resin may provide some benefit in terms of mechanical properties, regardless of the self-healing effect. For example, polyurethane (PU) nanocapsules $(\sim 500 \mathrm{~nm})$ containing TEGDMA were synthesized and loaded into a commercial two-step, single-bottle adhesive system. Crack healing was not expected, as no extra initiators were incorporated. Still, a significantly higher bond strength to dentin was verified for the material containing $9 \mathrm{wt} \%$ of nanocapsules, possibly due to a toughening effect provided by the flexible PU shells. ${ }^{58}$

Concerns about the biological safety of DCPD ${ }^{59}$ prompted the research of different self-repair systems for dental composites, also based on microencapsulated healing agents. Reports on the use of poly(urea formaldehyde) microcapsules (average diameter: $70 \mu \mathrm{m})$ filled with TEGDMA and a tertiary amine (N,N-dihydroxyethyl-p-toluidine, DHEPT) as activator in experimental composites were recently published. ${ }^{60,61,62}$ This self-repair system uses benzoyl peroxide (BPO) added to the resin matrix as initiator to polymerize the healing liquid. In the first study, ${ }^{62}$ these microcapsules were added to a BisGMA-TEGDMA resin. For microcapsule mass fractions up to $15 \%$, no adverse effects were observed in flexural properties while $\mathrm{K}_{\mathrm{lc}}$ increased by $40 \%$ at the maximum microcapsule loading. Healing efficiency showed a plateau starting at $10 \%$ of microcapsules, of approximately $65 \%$. In a follow-up study, experimental composites containing 35\% of reinforcing fillers, $20 \mathrm{wt} \%$ of ACP nanoparticles (to foster remineralization), $3.75 \mathrm{wt} \%$ of an antibacterial agent (dimethylaminohexadecyl methacrylate, DMAHDM), 0.5 $w t \%$ of $\mathrm{BPO}$ and different mass fractions of TEGDMADHEPT microcapsules were tested. The initial $\mathrm{K}_{\mathrm{lc}}$ was not affected by the presence of microcapsules up to $7.5 \mathrm{wt} \%$. Twenty-four hours after repositioning the fragments in the mold, specimens were re-tested and healing efficiency was found to be linearly related to microcapsule content, ranging from $25 \%$ (2.5 wt $\%$ of microcapsules) to $81 \%$ (10 wt $\%$ ). ${ }^{61}$ Healing efficiency of composites with $7.5 \%$ of TEGDMA-DHEPT microcapsules was not affected by prolonged water storage of the specimen prior to initial $\mathrm{K}_{\mathrm{lc}}$ test (up to six months), or when healing took place in water. ${ }^{60}$

A self-healing dental composite (or, more precisely, a compomer) based on glass ionomer cement chemistry was recently developed. ${ }^{52}$ Silanated silica microcapsules filled with an aqueous solution of polyacrylic acids (average diameter: $29 \mu \mathrm{m}$ ) were prepared and dispersed in an experimental composite containing a photocurable BisGMA/HEMA matrix and $70 \mathrm{wt} \%$ of strontium fluoroaluminasilicate glass 
particles. The idea was to form a reparative glass ionomer cement in the crack when the healing liquid is released. Microcapsule silanization was used to improve the interfacial strength between the shell and the resin matrix to favor its rupture rather than interfacial debonding upon meeting with the crack front. Re-testing $\mathrm{K}_{1 \mathrm{c}}$ specimens after four days allowed a maximum healing efficiency of $25 \%$, obtained with a microcapsules content of $10 \mathrm{wt} \%$.

\section{Strategy 3A: Remineralizing composites}

Calcium orthophosphate $(\mathrm{CaP})$ particles have been studied as ion-releasing fillers in resin-based composites for decades. ${ }^{63,64}$ Calcium and phosphate ions released from the composite would make the surrounding medium supersaturated, favoring their deposition on the enamel hydroxyapatite (HAP) crystals.$^{65}$ Several $\mathrm{CaP}$ phases have been tested as bioactive fillers in restorative composites, for example, amorphous calcium phosphate $(\mathrm{ACP}){ }^{66,67}$ dicalcium phosphate dihydrate (DCPD) ${ }^{68}$ dicalcium phosphate anhydrous (DCPA) ${ }^{69}$ and tetracalcium phosphate (TTCP). ${ }^{70}$

The efficacy of CaP-containing composites in promoting mineral recovery of dental tissues were demonstrated in several studies. For example, a material containing $40 \mathrm{wt} \%$ of ACP in a BisGMA/TEGDMA/HEMA matrix was capable of recovering $71 \%$ of the enamel mineral content of non-cavitated bovine enamel lesions after four weeks under a static remineralization model and 38\% after two weeks under $\mathrm{pH}$ cycling (dynamic model) ${ }^{64}$ A resin cement containing $20 \mathrm{wt} \%$ of DCPA particles $(1.1 \mu \mathrm{m})$, $60 \mathrm{wt} \%$ of TTCP particles $(16 \mu \mathrm{m})$ and $1.5 \%$ of sodium hexafluorosilicate in contact with demineralized human dentin promoted an increase in mineral in mineral content between $38 \%$ and $47 \%$ after 5 -week immersion in saliva-like solution. ${ }^{71} \mathrm{~A}$ resin-based material containing $40 \mathrm{wt} \%$ of $\mathrm{Zr}$-modified ACP $(55 \mu \mathrm{m})$ dispersed in a BisGMA/TEGDMA/HEMA matrix led to a $14 \%$ mineral recovery in non-cavitated human enamel lesions after 30 days of $\mathrm{pH}$ cycling. ${ }^{72}$ The first study associating ACP nanoparticles $(116 \mathrm{~nm}$, $40 \mathrm{wt} \%)$ and reinforcing glass fillers (1.4 $\mu \mathrm{m}, 20 \mathrm{wt} \%)$ in a BisEMA/TEGDMA/HEMA matrix verified a $22 \%$ remineralization in $\mathrm{pH}$ cycling conditions similar to those used in the previous study. ${ }^{63}$ It is interesting to point out that these in vitro studies share the characteristic of formulating their experimental materials with fairly hydrophilic resin matrices, which facilitates fluid transit through the material, consequently increasing ion release. Also, notice that experimental models utilizing $\mathrm{pH}$ cycling result in lower mineral recovery in comparison to static remineralization models (i.e., immersion in calcium solutions). The protective effect of CaP-containing composites against enamel demineralization was verified in an in situ study. Cavity preparations in human enamel fragments were restored with an experimental composite containing ACP $(116 \mathrm{~nm}$, $40 \mathrm{wt} \%)$ and glass fillers $(1.4 \mu \mathrm{m}, 20 \mathrm{wt} \%)$ in a less hydrophilic matrix (BisGMA/TEGDMA). After 14 days in the presence of biofilm, mineral loss was $59 \%$ lower in fragments restored with the ACP-containing composite in comparison to a control. ${ }^{73}$

Composites containing $\mathrm{CaP}$ particles are considered "smart materials" because ion release increases in more acidic conditions due to an increase in particle erosion. ${ }^{74}$ Also, in order to maximize ion release, particles with high surface area are preferable. ${ }^{75}$ Ion release increases exponentially with particle volume fraction. ${ }^{76}$ Finally, the hydrophilicity of the resin matrix must also be taken into account, as it interferes with the water access to the particles and, consequently, with ion release. ${ }^{77}$ As it could be expected, ion release does not occur indefinitely and fine-tuning all the variables to come up with a material able to provide a long-lasting protection against demineralization is challenging. Recently, it was demonstrated that a composite containing $20 \mathrm{wt} \%$ ACP and $50 \mathrm{wt} \%$ silanated glass was capable of recharging after complete exhausting its ion release (after 70-days immersion at $\mathrm{pH}=4$ ) by immersion in calcium and phosphate solutions (one minute, 3x/day, for three days). ${ }^{78}$

Although high volume fractions of $\mathrm{CaP}$ particles may increase the composite remineralizing potential, their presence in the material may cause a significant reduction in some of its mechanical properties. . $8,70,79$ For example, an experimental composite containing $40 \mathrm{vol} \%$ of reinforcing glass $(0.5 \mu \mathrm{m})$ and $20 \mathrm{vol} \%$ of DCPD $(8 \mu \mathrm{m})$ presented a $28 \%$ lower flexural strength in comparison with a control containing $60 \mathrm{vol} \%$ glass fillers. $\mathrm{K}_{\mathrm{Ic}}$ was initially improved with the replacement 
of some of the glass fillers with DCPD. However, after 28 days of storage in water, a $35 \%$ reduction was observed in the DCPD-containing composite, while no significant change in occurred in the control. ${ }^{68}$

The main cause of the negative effect of $\mathrm{CaP}$ particles on the mechanical properties is the lack of a strong chemical bonding between them and the resin matrix. ${ }^{70,80}$ To eliminate or at least reduce this limitation, functionalization of the CaP particles was attempted. ${ }^{81,82}$ The use of silane to functionalize DCPA particles caused a significant increase in composite fracture strength, compared to a control containing non-silanized DCPA; however, ion release was compromised due to the silane hydrophobic character, which hinders the access of water to the particles. ${ }^{75}$ Good mechanical results were also obtained when HAP particles were treated with acrylic and methacrylic acids. Unfortunately, ion release was not tested. ${ }^{82}$ Recently, the synthesis of TEGDMA-functionalized DCPD particles was described. ${ }^{83}$ TEGDMA is capable of bonding to $\mathrm{Ca}^{2+}$ via ion-dipole interactions with the oxygen atoms from the ethylene glycol groups. The incorporation of $20 \mathrm{vol} \%$ of these particles in a BisGMA/TEGDMA resin resulted in a $32 \%$ increase in flexural strength in comparison to the material containing non-functionalized particles. ${ }^{84}$ A similar improvement was observed in a subsequent study where an experimental composite containing $40 \mathrm{vol} \%$ of barium glass $(0.5 \mu \mathrm{m})$ and $20 \mathrm{vol} \%$ of TEGDMA-functionalized DCPD $(19 \mu \mathrm{m})$ was compared to a similar formulation containing non-functionalized DCPD. ${ }^{85}$

Composites containing $\mathrm{CaP}$ particles may undergo more severe degradation after prolonged water immersion than their conventional counterparts, possibly due to the higher water sorption allowed by the transit of fluids along CaP-matrix interfaces. ${ }^{86}$ For example, composites containing DCPD particles showed up to $33 \%$ reduction in flexural strength after 28 days in water versus a $16 \%$ reduction for composites without DCPD. ${ }^{68}$ But no difference in strength was observed after two years of immersion in water for composites containing $10-20 \mathrm{wt} \%$ of ACP nanoparticles $(112 \mathrm{~nm})$ and $65-50 \mathrm{wt} \%$ of barium glass $(1.4 \mu \mathrm{m})$ and the control with $75 \mathrm{wt} \%$ of glass fillers. ${ }^{87}$

Despite all the research activity involving $\mathrm{CaP}$ composites, it seems that the concept has not yet been embraced by dental materials manufacturers. The sole exception is a restorative composite containing $38 \mathrm{wt} \%$ ACP, released in 2012 (Aegis V, Bosworth, Skokie, USA). Literature reports and manufacturer information are scarce. Its flexural strength is reduced, comparable to that of a microhybrid composite, which explains its indication only for restoring class $\mathrm{V}$ cavities. From the same manufacturer, $\mathrm{ACP}$-containing sealant and orthodontic cement showed remineralizing potential similar to fluoride-containing materials in vitro. ${ }^{88,89}$

\section{Strategy 3B: Antibacterial composites}

While adhesive systems containing antibacterial agents have been on the market for several years, restorative composites with antibacterial activity are still under development. Ideally, antibacterial composites must meet a critical set of requirements, including: 1) non-toxicity, ${ }^{90}$ 2) antibacterial action against a broad spectrum of microorganisms ${ }^{91}$ and 3 ) maintain a long-lasting effect. ${ }^{92,93}$ Also, it is very important that incorporation of antibacterial agents does not compromise the mechanical and optical properties of the restorative material. ${ }^{93,94}$

The association between quaternary ammonium (QAM) and methacrylate terminal groups results in an antibacterial monomer with low lixiviation (i.e., leaching) levels. ${ }^{90,91,92,95}$ The first attempt of incorporating a copolymerizable antibacterial monomer in experimental composites was reported more than 20 years ago. When MDPB (12-methacryloyloxydodecylpyridinium bromide was incorporated into a BisGMA/TEGDMA composite (filler fraction: $83 \mathrm{wt} \%$ ) in $0.1 \mathrm{wt} \%$ and $0.2 \mathrm{wt} \%$ fractions, the growth of S.mutans on the composite surface was inhibited for up to 90 days, without significant effects on the composite flexural properties. ${ }^{96}$ The proposed antibacterial mechanism for these monomers is that quaternary ammonium would damage the bacterial cell membrane, leading to cell death..$^{90}$

QAMs were also incorporated within experimental composites associated with polyethyleneimine nanoparticles $(140 \mathrm{~nm})$. Due to their positive charge, these nanoparticles (QPEI) are attracted to the bacterial cell membrane. This charge imbalance increases cell permeability, ultimately leading to disruption of the cell membrane. ${ }^{97}$ The incorporation of $1 \mathrm{wt} \%$ of these nanoparticles into commercial composites did not 
reduce their initial flexural properties and inhibited the growth of $S$ mutans and A viscous for up to four weeks. ${ }^{98}$

Another example of an antibacterial monomer with methacrylate functionality is dimethylaminohexadecyl methacrylate (DMAHDM). It has been tested in association with a protein-repellent biopolymer, 2-methacryloyloxyethyl phosphorylcholine (MPC), which reduces bacterial adsorption on the composite surface. Composites containing $70 \mathrm{wt} \%$ of glass fillers and $1.5 \mathrm{wt} \%$ of DMAHDM, associated with $3 \mathrm{wt} \%$ of MPC showed higher antibacterial activity against cariogenic and periopathogenic bacteria than either components alone. Flexural properties were not affected by the presence of either compound. ${ }^{99}$ However, MPC is hydrophilic and its presence significantly increases composite water sorption, which may accelerate matrix degradation. ${ }^{91}$

Bioactive glass (BAG) particles were also investigated as antibacterial agents in dental composites. An experimental BisGMA/TEGDMA composite with $57 \mathrm{wt} \%$ of reinforcing glass and $15 \mathrm{wt} \%$ BAG particles (0.04-3 $\mu \mathrm{m}, \mathrm{SiO}_{2}, \mathrm{CaO}$ and $\mathrm{P}_{2} \mathrm{O}_{5}$ ) were shown to reduce bacterial penetration into the tooth-restoration interface and tooth demineralization in comparison to a control. The possible hypothesis for bacterial inhibition is a local increase in $\mathrm{pH}$ and/or some of the ions directly affecting bacteria. ${ }^{100}$ Silver-doped BAG particles $(25 \mu \mathrm{m}$, $\mathrm{SiO}_{2}-\mathrm{CaO}-\mathrm{P}_{2} \mathrm{O}_{5}-\mathrm{Al}_{2} \mathrm{O}_{3}-\mathrm{Na}_{2} \mathrm{O}-\mathrm{K}_{2} \mathrm{O}-\mathrm{Ag}_{2} \mathrm{O}$ ) incorporated into a commercial flowable composite at mass fractions of $5 \%$ and $15 \%$ resulted in significant reduction in $S$ mutans activity. As $\mathrm{pH}$ remained stable throughout the study, antibacterial activity was ascribed to $\mathrm{Ag}^{+}$ ion release from the material. ${ }^{101}$

Though composites containing silver compounds or metallic silver $\left(\mathrm{Ag}^{0}\right)$ nanoparticles have shown great efficacy against bacteria without compromising their mechanical properties, ${ }^{102}$ their presence even in small concentrations causes significant darkening of the composite. ${ }^{103}$ Zinc oxide particles have a more tooth-like color and were shown to possess antibacterial activity probably due to the release of $\mathrm{Zn}^{2+}$ ions, which inhibit the metabolism of sugars and interfere with bacterial enzymatic activity by displacing $\mathrm{Mg}^{2+}$ ions. ${ }^{104}$ Their efficacy, however, is much lower than that of silver, as $10 \mathrm{wt} \%$ of $\mathrm{ZnO}$ nanoparticles $(40-100 \mathrm{~nm})$ added to a commercial composite showed significant lower
Streptococci inhibition compared to $1 \mathrm{wt} \%$ of silver. ${ }^{104}$ In another study, the incorporation of up to $5 \mathrm{wt} \%$ of $\mathrm{ZnO}$ nanoparticles $(20 \mathrm{~nm})$ to a commercial flowable composite significantly inhibited $S$. mutans growth in non-aged and 48-h aged specimens. However, specimens aged for one week and four weeks did not show any inhibitory effect. ${ }^{94}$

Chlorhexidine (CHX) was also investigated as an antimicrobial agent in composites. Because CHX salts are not soluble in the resin matrix, they tend to form relatively large agglomerates, which negatively affects composite mechanical properties. ${ }^{105}$ To overcome these problems, CHX was loaded into mesoporous silica nanoparticles (MSNs), with significant improvements in mechanical properties compared to materials containing directly added CHX. Furthermore, composites with MSNs sustained a lower surface roughness and allowed for a more controlled $\mathrm{CHX}$ release over time. ${ }^{93}$

\section{Final Remarks: Can All These Strategies Co-Exist?}

Some of the above strategies may be mutually exclusive, because there are practical limits to intelligent addition of multiple chemicals - especially to a unitary (light cured) material formulation. Also, with selfadhesive materials there may be limited shelf life due to the incorporation of reactive chemicals. However the strategies $2 \mathrm{~A}$ and $2 \mathrm{~B}$ to produce stronger composites might be compatible by incorporation of both fibers and self-healing capsules into the resin matrix. Despite the great potential of bulk fill composites, it may be desirable to have separate base-layer composites with anti-microbial and/or remineralizing functionality. It seems inevitable that some kind of trade off will still be required between ease/simplicity of application and the number of material functions desired and achievable. It is important that some of these strategies be advanced from in vitro to in situ studies, and then to controlled clinical trials.

Meanwhile, with the present composite materials available, it is essential to deploy them optimally, particularly by optimal light curing. The consequences of failing to do so are serious for restoration longevity. But that is another story. 


\section{References}

1. Ferracane JL. Resin composite: state of the art. Dent Mater. 2011;27(1):29-38. https://doi.org/10.1016/i.dental.2010.10.020

2. Braga RR, Ferracane JL. Alternatives in polymerization contraction stress management. Crit Rev Oral Biol Med. 2004;15(3):176-84. https://doi.org/10.1177/154411130401500306

3. Fronza BM, Rueggeberg FA, Braga RR, Mogilevych B, Soares LE, Martin AA et al. Monomer conversion, microhardness, internal marginal adaptation, and shrinkage stress of bulk-fill resin composites. Dent Mater. 2015;31(12):1542-51. https://doi.org/10.1016/i.dental.2015.10.001

4. Rasines Alcaraz MG, Veitz-Keenan $A$, Sahrmann P, Schmidlin PR, Davis D, Iheozor-Ejiofor Z. Direct composite resin fillings versus amalgam fillings for permanent or adult posterior teeth. Cochrane Database Syst Rev. 2014(3):CD005620. https://doi.org/10.1002/14651858.CD005620.pub2

5. Nedelikovic I, Teughels W, De Munck J, Van Meerbeek B, Van Landuyt KL. Is secondary caries with composites a material-based problem? Dent Mater. 2015;31(11):e247-77. https://doi.org/10.1016/i.dental.2015.09.001

6. Beck F, Lettner S, Graf A, Bitriol B, Dumitrescu N, Baver $P$ et al. Survival of direct resin restorations in posterior teeth within a 19-year period (1996-2015): A meta-analysis of prospective studies. Dent Mater. 2015;31(8):958-85. https://doi.org/10.1016/i.dental.2015.05.004

7. Opdam NJ, van de Sande FH, Bronkhorst E, Cenci MS, Bottenberg $\mathrm{P}$, Pallesen $\mathrm{U}$ et al. Longevity of posterior composite restorations: a systematic review and meta-analysis. J Dent Res. 2014;93(10):943-9. https://doi.org/10.1177/0022034514544217

8. Altunsoy M, Botsali MS, Sari T, Onat H. Effect of different surface treatments on the microtensile bond strength of two self-adhesive flowable composites. Lasers Med Sci. 2015;30(6):1667-73. https://doi.org/10.1007/s10103-014-1640-2

9. Goracci C, Margvelashvili M, Giovannetti A, Vichi A, Ferrari M. Shear bond strength of orthodontic brackets bonded with a new self-adhering flowable resin composite. Clin Oral Investig. 2013;17(2):609-17. https://doi.org/10.1007/s00784-012-0729-x

10. Ferracane JL, Stansbury JW, Burke FJ. Self-adhesive resin cements - chemistry, properties and clinical considerations. J Oral Rehabil. 2011;38(4):295-314. https://doi.org/10.1111/j.1365-2842.2010.02148.x

11. Van Meerbeek B, Peumans M, Poitevin A, Mine A, Van Ende A, Neves $A$ et al. Relationship between bond-strength tests and clinical outcomes. Dent Mater. 2010;26(2):e100-21. https://doi.org/10.1016/j.dental.2009.11.148
12. Vichi A, Margvelashvili M, Goracci C, Papacchini F, Ferrari M. Bonding and sealing ability of a new self-adhering flowable composite resin in class I restorations. Clin Oral Investig. 2013;17(6):1497-506. https://doi.org/10.1007/s00784-012-0846-6

13. Van Landuyt KL, Snauwaert J, De Munck J, Peumans M, Yoshida Y, Poitevin A et al. Systematic review of the chemical composition of contemporary dental adhesives. Biomaterials. 2007;28(26):3757-85. https://doi.org/10.1016/i.biomaterials.2007.04.044

14. Rengo C, Goracci C, Juloski J, Chieffi N, Giovannetti A, Vichi $A$ et al. Influence of phosphoric acid etching on microleakage of a self-etch adhesive and a self-adhering composite. Aust Dent J. 2012;57(2):220-6. https://doi.org/10.1111/j.1834-7819.2012.01689.x

15. Bektas OO, Eren D, Akin EG, Akin H. Evaluation of a self-adhering flowable composite in terms of micro-shear bond strength and microleakage. Acta Odontol Scand. 2013;71(3-4):541-6. https://doi.org/10.3109/00016357.2012.696697

16. Miyazaki M, Ando S, Hinoura K, Onose H, Moore BK. Influence of filler addition to bonding agents on shear bond strength to bovine dentin. Dent Mater. 1995;11(4):234-8. https://doi.org/10.1016/0109-5641(95)80055-7

17. Yoshida Y, Nagakane K, Fukuda R, Nakayama Y, Okazaki M, Shintani $\mathrm{H}$ et al. Comparative study on adhesive performance of functional monomers. J Dent Res. 2004;83(6):454-8. https://doi.org/10.1177/154405910408300604

18. Monticelli F, Osorio R, Mazzitelli C, Ferrari M, Toledano M. Limited decalcification/diffusion of self-adhesive cements into dentin. J Dent Res. 2008;87(10):974-9. https://doi.org/10.1177/154405910808701012

19. Poitevin A, De Munck J, Van Ende A, Suyama Y, Mine A, Peumans $M$ et al. Bonding effectiveness of self-adhesive composites to dentin and enamel. Dent Mater. 2013;29(2):221-30. https://doi.org/10.1016/i.dental.2012.10.001

20. Goracci C, Cadenaro M, Fontanive L, Giangrosso G, Juloski J, Vichi A et al. Polymerization efficiency and flexural strength of low-stress restorative composites. Dent Mater. 2014;30(6):688-94. https://doi.org/10.1016/j.dental.2014.03.006

21. Tuloglu N, Sen Tunc E, Ozer S, Bayrak S. Shear bond strength of self-adhering flowable composite on dentin with and without application of an adhesive system. J Appl Biomater Funct Mater. 2014;12(2):97-101. https://doi.org/10.5301/jabfm.5000166

22. Makishi P, Pacheco RR, Sadr A, Shimada Y, Sumi $Y$, Tagami J et al. Assessment of Self-Adhesive Resin Composites: Nondestructive Imaging of Resin-Dentin Interfacial Adaptation and Shear Bond Strength. Microsc Microanal. 2015;21(6):1523-9. https://doi.org/10.1017/S1431927615015354 
23. Sachdeva P, Goswami M, Singh D. Comparative evaluation of shear bond strength and nanoleakage of conventional and self-adhering flowable composites to primary teeth dentin. Contemp Clin Dent. 2016;7(3):326-31. https://doi.org/10.4103/0976-237X.188549

24. Fu J, Kakuda S, Pan F, Hoshika S, Ting S, Fukuoka $\mathrm{A}$ et al. Bonding performance of a newly developed step-less all-in-one system on dentin. Dent Mater J. 2013;32(2):203-11. https://doi.org/10.4012/dmi.2012-204

25. Giachetti L, Scaminaci Russo D, Baldini M, Bertini F, Steier L, Ferrari M. Push-out strength of translucent fibre posts cemented using a dual-curing technique or a light-curing self-adhering material. Int Endod J. 2012;45(3):249-56. https://doi.org/10.1111/j.1365-2591.2011.01969.x

26. Mobarak E, Seyam R. Interfacial nanoleakage and bonding of self-adhesive systems cured with a modified-layering technique to dentin of weakened roots. Oper Dent. 2013;38(5):E154-65. https://doi.org/10.2341/12-103-L

27. İşman $E$, Karaarslan ES, Okşayan R, Tunçdemır AR, Üşümez $\mathrm{S}$, Adanir $\mathrm{N}$ et al. Inadequate shear bond strengths of self-etch, self-adhesive systems for secure orthodontic bonding. Dent Mater J. 2012;31(6):947-53. https://doi.org/10.4012/dmj.2012-103

28. Eliades A, Birpou E, Eliades T, Eliades G. Self-adhesive restoratives as pit and fissure sealants: a comparative laboratory study. Dent Mater. 2013;29(7):752-62. https://doi.org/10.1016/i.dental.2013.04.005

29. Yazici AR, Agarwal I, Campillo-Funollet M, Munoz-Viveros C, Antonson SA, Antonson DE et al. Effect of laser preparation on bond strength of a self-adhesive flowable resin. Lasers Med Sci. 2013;28(1):343-7. https://doi.org/10.1007/s10103-012-1158-4

30. Çelik EU, Aka B, Yilmaz F. Six-month clinical evaluation of a self-adhesive flowable composite in noncarious cervical lesions. J Adhes Dent. 2015;17(4):361-8. https://doi.org/10.3290/j.jad.a34556

31. Czasch P, llie N. In vitro comparison of mechanical properties and degree of cure of a self-adhesive and four novel flowable composites. J Adhes Dent. 2013;15(3):229-36. https://doi.org/10.3290/i.jad.a29530

32. Malavasi CV, Macedo EM, Souza KC, Rego GF, Schneider LF, Cavalcante LM. Surface texture and optical properties of self-adhering composite materials after toothbrush abrasion. J Contemp Dent Pract. 2015;16(10):775-82. https://doi.org/10.5005/ip-journals-10024-1756

33. Söderholm KJ, Lambrechts $P$, Sarrett $D, A b e Y$, Yang MC, Labella $R$, et al. Clinical wear performance of eight experimental dental composites over three years determined by two measuring methods. Eur J Oral Sci. 2001;109(4):273-81. https://doi.org/10.1034/i.1600-0722.2001.00064.x

34. Wei YJ, Silikas N, Zhang ZT, Watts DC.

Hygroscopic dimensional changes of self-adhering and new resin-matrix composites during water sorption/desorption cycles. Dent Mater. 2011;27(3):259-66. https://doi.org/10.1016/j.dental.2010.10.015
35. Wei YJ, Silikas N, Zhang ZT, Watts DC. Diffusion and concurrent solubility of self-adhering and new resin-matrix composites during water sorption/desorption cycles. Dent Mater. 2011;27(2):197-205. https://doi.org/10.1016/i.dental.2010.10.014

36. Krause WR, Park SH, Straup RA. Mechanical properties of BIS-GMA resin short glass fiber composites. J Biomed Mater Res. 1989;23(10):1195-211. https://doi.org/10.1002/jbm.820231008

37. Choi KK, Ferracane JL, Hilton TJ, Charlton D. Properties of packable dental composites. J Esthet Dent. 2000;12(4):216-26. https://doi.org/10.1111/j.1708-8240.2000.tb00224.x

38. Knobloch LA, Kerby RE, Seghi R, Berlin JS, Clelland N. Fracture toughness of packable and conventional composite materials. J Prosthet Dent. 2002;88(3):307-13. https://doi.org/10.1067/mpr.2002.128069

39. Lassila L, Garoushi S, Vallittu PK, Säilynoja E. Mechanical properties of fiber reinforced restorative composite with two distinguished fiber length distribution. J Mech Behav Biomed Mater. 2016;60:331-8. https://doi.org/10.1016/i.jmbbm.2016.01.036

40. Garoushi SK, Hatem M, Lassila LVJ, Vallittu PK. The effect of short fiber composite base on microleakage and load-bearing capacity of posterior restorations. Acta Biomater Odontol Scand. 2015;1(1):6-12. https://doi.org/10.3109/23337931.2015.1017576.

41. Leprince JG, Palin WM, Vanacker J, Sabbagh J, Devaux J, Leloup G. Physico-mechanical characteristics of commercially available bulk-fill composites. J Dent. 2014;42(8):993-1000. https://doi.org/10.1016/i.jdent.2014.05.009

42. Barreto BC, Van Ende A, Lise DP, Noritomi PY, Jaecques S, Sloten JV et al. Short fibre-reinforced composite for extensive direct restorations: a laboratory and computational assessment. Clin Oral Investig. 2016;20(5):959-66 https://doi.org/10.1007/s00784-015-1576-3

43. Garoushi S, Säilynoja E, Vallittu PK, Lassila L. Physical properties and depth of cure of a new short fiber reinforced composite. Dent Mater. 2013;29(8):835-41. https://doi.org/10.1016/j.dental.2013.04.016

44. Petersen RC. Discontinuous fiber-reinforced composites above critical length. J Dent Res. 2005;84(4):365-70. https://doi.org/10.1177/154405910508400414

45. Shouha P, Swain M, Ellakwa A. The effect of fiber aspect ratio and volume loading on the flexural properties of flowable dental composite. Dent Mater. 2014;30(11):1234-44. https://doi.org/10.1016/i.dental.2014.08.363

46. Bocalon AC, Mita D, Narumyia I, Shouha P, Xavier TA, Braga RR. Replacement of glass particles by multidirectional short glass fibers in experimental composites: effects on degree of conversion, mechanical properties and polymerization shrinkage. Dent Mater. 2016;32(9):e204-10. https://doi.org/10.1016/i.dental.2016.06.008 
47. Bijelic-Donova J, Garoushi S, Lassila LV, Keulemans F, Vallittu PK. Mechanical and structural characterization of discontinuous fiber-reinforced dental resin composite. J Dent. 2016;52:70-8. https://doi.org/10.1016/i.jdent.2016.07.009

48. Quinn GD. Fractography of ceramics and glasses. Gaithersburg: National Institute of Standards and Technology; 2007.

49. Tezvergil A, Lassila LV, Vallittu PK. The effect of fiber orientation on the polymerization shrinkage strain of fiber-reinforced composites. Dent Mater. 2006;22(7):610-6. https://doi.org/10.1016/i.dental.2005.05.017

50. Shouha PS, Ellakwa AE. Effect of short glass fibers on the polymerization shrinkage stress of dental composite. J Biomed Mater Res B Appl Biomater. 2016. https://doi.org/10.1002/jbm.b.33723

51. Ornaghi BP, Meier MM, Lohbaver U, Braga RR. Fracture toughness and cyclic fatigue resistance of resin composites with different filler size distributions. Dent Mater. 2014;30(7):742-51. https://doi.org/10.1016/i.dental.2014.04.004

52. Huyang G, Debertin AE, Sun J. Design and development of self-healing dental composites. Mater Des. 2016;94:295-302. https://doi.org/10.1016/i.matdes.2016.01.046

53. Dry C. Procedures developed for self-repair of polymer matrix composite materials. Compos Struct. 1996;35(3):263-9. https://doi.org/10.1016/0263-8223(96)00033-5

54. White SR, Sottos NR, Geubelle PH, Moore JS, Kessler MR, Sriram SR, et al. Autonomic healing of polymer composites. Nature. 2001;409(6822):794-7. https://doi.org/10.1038/35057232

55. Caruso MM, Blaiszik BJ, White SR, Sottos NR, Moore JS. Full recovery of fracture toughness using a nontoxic solvent-based self-healing system. Adv Funct Mater. 2008;18(13):1898-904. https://doi.org/10.1002/adfm.200800300

56. Brown EN, White SR, Sottos NR. Retardation and repair of fatigue cracks in a microcapsule toughened epoxy composite - Part II: in situ self-healing. Compos Sci Technol. 2005;65(15-16):2474-80. https://doi.org/10.1016/i.compscitech.2005.04.053.

57. Wertzberger BE, Steere JT, Pfeifer RM, Nensel MA, Latta MA, Gross SM. Physical characterization of a self-healing dental restorative material. J Appl Polym Sci. 2010;118(1):428-34. https://doi.org/10.1002/app.31542

58. Ouyang X, Huang X, Pan Q, Zuo C, Huang C, Yang X et al. Synthesis and characterization of triethylene glycol dimethacrylate nanocapsules used in a self-healing bonding resin. J Dent. 2011;39(12):825-33. https://doi.org/10.1016/j.jdent.2011.09.001

59. Kransler KM. Results of a 90-day inhalation study of dicyclopentadiene in $\mathrm{B} 6 \mathrm{C} 3 \mathrm{~F} 1$ mice. Toxicol Ind Health. 2014;30(5):459-66. https://doi.org/10.1177/0748233712458481

60. Wu J, Weir MD, Melo MA, Strassler HE, Xu HH. Effects of water-aging on self-healing dental composite containing microcapsules. J Dent. 2016;47:86-93. healing dental composite containing microcapsules. J Dent 2016 Apr;47:86-93. https://doi.org/10.1016/i.jdent.2016.01.008
61. Wu J, Weir MD, Melo MA, Xu HH. Development of novel self-healing and antibacterial dental composite containing calcium phosphate nanoparticles. J Dent. 2015;43(3):317-26. https://doi.org/10.1016/i.jdent.2015.01.009

62. Wu J, Weir MD, Zhang Q, Zhou C, Melo MA, $\mathrm{Xu} \mathrm{HH}$. Novel self-healing dental resin with microcapsules of polymerizable triethylene glycol dimethacrylate and N,N-dihydroxyethyl-p-tolvidine. Dent Mater. 2016;32(2):294-304. https://doi.org/10.1016/j.dental.2015.11.014

63. Weir MD, Chow LC, Xu HH. Remineralization of demineralized enamel via calcium phosphate nanocomposite. J Dent Res. 2012;91(10):979-84. https://doi.org/10.1177/0022034512458288

64. Skrtic D, Hailer AW, Takagi S, Antonucci JM, Eanes ED. Quantitative assessment of the efficacy of amorphous calcium phosphate/methacrylate composites in remineralizing caries-like lesions artificially produced in bovine enamel. J Dent Res. 1996;75(9):1679-86. https://doi.org/10.1177/00220345960750091001

65. Cochrane NJ, Cai F, Huq NL, Burrow MF, Reynolds EC. New approaches to enhanced remineralization of tooth enamel. J Dent Res. 2010;89(11):1187-97. https://doi.org/10.1177/0022034510376046

66. Marovic D, Tarle Z, Hiller KA, Müller R, Ristic M, Rosentritt $M$ et al. Effect of silanized nanosilica addition on remineralizing and mechanical properties of experimental composite materials with amorphous calcium phosphate. Clin Oral Investig. 2014;18(3):783-92. https://doi.org/10.1007/s00784-013-1044-x

67. Xu HH, Moreau JL, Sun L, Chow LC. Nanocomposite containing amorphous calcium phosphate nanoparticles for caries inhibition. Dental Mater. 2011;27(8):762-9. https://doi.org/10.1016/j.dental.2011.03.016

68. Chiari MD, Rodrigues MC, Xavier TA, de Souza EM, Arana-Chavez VE, Braga RR. Mechanical properties and ion release from bioactive restorative composites containing glass fillers and calcium phosphate nano-structured particles. Dent Mater. 2015;31(6):726-33. https://doi.org/10.1016/j.dental.2015.03.015

69. Xu HH, Weir MD, Sun L, Takagi S, Chow LC. Effects of calcium phosphate nanoparticles on Ca-PO4 composite. J Dent Res. 2007;86(4):378-83. https://doi.org/10.1177/154405910708600415

70. $\mathrm{Xu} \mathrm{HH}$, Moreau JL. Dental glass-reinforced composite for caries inhibition: calcium phosphate ion release and mechanical properties. J Biomed Mater Res B Appl Biomater. 2010;92(2):332-40. https://doi.org/10.1002/jbm.b.31519

71. Dickens SH, Flaim GM, Takagi S. Mechanical properties and biochemical activity of remineralizing resin-based Ca-PO4 cements. Dent Mater. 2003;19(6):558-66. https://doi.org/10.1016/S0109-5641(02)00105-7 
72. Langhorst SE, O'Donnell JN, Skrtic D. In vitro remineralization of enamel by polymeric amorphous calcium phosphate composite: quantitative microradiographic study. Dent Mater. 2009;25(7):884-91. https://doi.org/10.1016/i.dental.2009.01.094

73. Melo MA, Weir MD, Rodrigues LK, Xu HH. Novel calcium phosphate nanocomposite with caries-inhibition in a human in situ model. Dent Mater. 2013;29(2):231-40. https://doi.org/10.1016/i.dental.2012.10.010

74. $\mathrm{Xu} \mathrm{HH}$, Weir MD, Sun L. Calcium and phosphate ion releasing composite: effect of $\mathrm{pH}$ on release and mechanical properties. Dent Materer. 2009;25(4):535-42. https://doi.org/10.1016/i.dental.2008.10.009

75. Xu HH, Weir MD, Sun L. Nanocomposites with $\mathrm{Ca}$ and $\mathrm{PO} 4$ release: effects of reinforcement, dicalcium phosphate particle size and silanization. Dent Mater. 2007;23(12):1482-91. https://doi.org/10.1016/j.dental.2007.01.002

76. Xu HH, Weir MD, Sun L, Moreau JL, Takagi S, Chow LC et al. Strong nanocomposites with $\mathrm{Ca}, \mathrm{PO}(4)$, and $\mathrm{F}$ release for caries inhibition. J Dent Res. 2010;89(1):19-28. https://doi.org/10.1177/0022034509351969

77. Skrtic D, Antonucci JM. Dental composites based on amorphous calcium phosphate resin composition/physicochemical properties study. J Biomater Appl. 2007;21 (4):375-93. https://doi.org/10.1177/0885328206064823

78. Zhang L, Weir MD, Chow LC, Antonucci JM, Chen J, $\mathrm{Xu} \mathrm{HH}$. Novel rechargeable calcium phosphate dental nanocomposite. Dental Mater. 2016;32(2):285-93. https://doi.org/10.1016/j.dental.2015.11.015

79. Aljabo A, Xia W, Liaqat S, Khan MA, Knowles JC, Ashley $\mathrm{P}$, et al. Conversion, shrinkage, water sorption, flexural strength and modulus of re-mineralizing dental composites. Dent Mater. 2015;31(11):1279-89. https://doi.org/10.1016/j.dental.2015.08.149

80. Dui M, Zheng Y. Modification of silica nanoparticles and their application in UDMA dental polymeric composites. Polym Compos. 2007;28(2):198-207. https://doi.org/10.1002/pc.20377

81. O'Donnell JN, Schumacher GE, Antonucci JM, Skrtic D. Structure-Composition-Property Relationships in Polymeric Amorphous Calcium Phosphate-Based Dental Composites. Materials (Basel). 2009;2(4):1929-59. https://doi.org/10.3390/ma2041929

82. Arcís RW, López-Macipe A, Toledano M, Osorio E, Rodríguez-Clemente R, Murtra J et al. Mechanical properties of visible light-cured resins reinforced with hydroxyapatite for dental restoration. Dent Mater. 2002;18(1):49-57. https://doi.org/10.1016/S0109-5641(01)00019-7

83. Rodrigues MC, Hewer TL, Brito GE, Arana-Chavez VE, Braga RR. Calcium phosphate nanoparticles functionalized with a dimethacrylate monomer. Mater Sci Eng C. 2014;45:122-6. https://doi.org/10.1016/i.msec.2014.08.066
84. Rodrigues MC, Xavier TA, Arana-Chavez VE, Braga RR. Polymer-based material containing calcium phosphate particles functionalized with a dimethacrylate monomer for use in restorative dentistry. J Biomater Appl. 2016;31(6):7.

85. Alania Y, Chiari MD, Rodrigues MC, Arana-Chavez VE, Bressiani AH, Vichi FM, et al. Bioactive composites containing TEGDMA-functionalized calcium phosphate particles: degree of conversion, fracture strength and ion release evaluation. Dent Mater. 2016;32(12):e374-e81. https://doi.org/10.1016/i.dental.2016.09.021

86. Skrtic D, Antonucci JM. Effect of bifunctional comonomers on mechanical strength and water sorption of amorphous calcium phosphate- and silanized glass-filled Bis-GMA-based composites. Biomaterials. 2003;24(17):2881-8. https://doi.org/10.1016/S0142-9612(03)00119-4

87. Moreau JL, Weir MD, Giuseppetti AA, Chow LC, Antonucci $J M, X u H H$. Long-term mechanical durability of dental nanocomposites containing amorphous calcium phosphate nanoparticles. J Biomed Mater Res B Appl Biomater. 2012;100(5):1264-73. https://doi.org/10.1002/jbm.b.32691

88. Silva KG, Pedrini D, Delbem AC, Ferreira L, Cannon M. In situ evaluation of the remineralizing capacity of pit and fissure sealants containing amorphous calcium phosphate and/or fluoride. Acta Odontol Scand. 2010;68(1):11-8. https://doi.org/10.3109/00016350903260264

89. Chow CK, Wu CD, Evans CA. In vitro properties of orthodontic adhesives with fluoride or amorphous calcium phosphate. Int J Dent. 2011;2011:ID583521. https://doi.org/10.1155/2011/583521

90. Antonucci JM, Zeiger DN, Tang K, Lin-Gibson S, Fowler BO, Lin NJ. Synthesis and characterization of dimethacrylates containing quaternary ammonium functionalities for dental applications. Dent Mater. 2012;28(2):219-28. https://doi.org/10.1016/i.dental.2011.10.004

91. Wang L, Xie X, Imazato S, Weir MD, Reynolds MA, Xu HH. A protein-repellent and antibacterial nanocomposite for Class-V restorations to inhibit periodontitis-related pathogens. Mater Sci Eng C. 2016;67:702-10. https://doi.org/10.1016/i.msec.2016.05.080

92. Cheng L, Zhang K, Zhou CC, Weir MD, Zhou XD, Xu HH. One-year water-ageing of calcium phosphate composite containing nano-silver and quaternary ammonium to inhibit biofilms. Int J Oral Sci. 2016;8(3):172-81. https://doi.org/10.1038/ijos.2016.13

93. Zhang JF, Wu R, Fan Y, Liao S, Wang Y, Wen ZT et al. Antibacterial dental composites with chlorhexidine and mesoporous silica. J Dent Res. 2014;93(12):1283-9. https://doi.org/10.1177/0022034514555143

94. Tavassoli Hojati S, Alaghemand H, Hamze F, Ahmadian Babaki F, Rajab-Nia R, Rezvani MB, et al. Antibacterial, physical and mechanical properties of flowable resin composites containing zinc oxide nanoparticles. Dent Mater. 2013;29(5):495-505. https://doi.org/10.1016/i.dental.2013.03.011 
Trends in restorative composites research: what is in the future?

95. Imazato S. Bio-active restorative materials with antibacterial effects: new dimension of innovation in restorative dentistry. Dent Mater J. 2009;28(1):11-9. https://doi.org/10.4012/dmi.28.11

96. Imazato S, Torii M, Tsuchitani Y, McCabe JF, Russell RR. Incorporation of bacterial inhibitor into resin composite. J Dental Res. 1994;73(8):1437-43. https://doi.org/10.1177/00220345940730080701

97. Pietrokovski Y, Nisimov I, Kesler-Shvero D, Zaltsman N, Beyth N. Antibacterial effect of composite resin foundation material incorporating quaternary ammonium polyethyleneimine nanoparticles. J Prosthet Dent. 2016;116(4):603-9. https://doi.org/10.1016/i.prosdent.2016.02.022

98. Beyth N, Yudovin-Farber I, Bahir R, Domb AJ, Weiss El. Antibacterial activity of dental composites containing quaternary ammonium polyethylenimine nanoparticles against Streptococcus mutans. Biomaterials. 2006;27(21):3995-4002. https://doi.org/10.1016/j.biomaterials.2006.03.003

99. Zhang N, Ma J, Melo MA, Weir MD, Bai Y, Xu HH. Protein-repellent and antibacterial dental composite to inhibit biofilms and caries. J Dent. 2015;43(2):225-34. https://doi.org/10.1016/i.jdent.2014.11.008

100. Khvostenko D, Hilton TJ, Ferracane JL, Mitchell JC, Kruzic JJ. Bioactive glass fillers reduce bacterial penetration into marginal gaps for composite restorations. Dent Mater. 2016;32(1):73-81. https://doi.org/10.1016/j.dental.2015.10.007

101. Chatzistavrou X, Velamakanni S, DiRenzo K, Lefkelidou A, Fenno JC, Kasuga T, et al. Designing dental composites with bioactive and bactericidal properties. Mater Sci Eng C. 2015;52:267-72. https://doi.org/10.1016/j.msec.2015.03.062

102. Cheng YJ, Zeiger DN, Howarter JA, Zhang X, Lin NJ, Antonucci JM et al. In situ formation of silver nanoparticles in photocrosslinking polymers. J Biomed Mater Res B Appl Biomater. 2011;97(1):124-31. https://doi.org/10.1002/jbm.b.31793

103. Fan C, Chu L, Rawls HR, Norling BK, Cardenas HL, Whang K. Development of an antimicrobial resin: a pilot study. Dent Mater. 2011;27(4):322-8.

104. Aydin Sevinç B, Hanley L. Antibacterial activity of dental composites containing zinc oxide nanoparticles. J

Biomed Mater Res B Appl Biomater. 2010;94(1):22-31. https://doi.org/10.1002/jbm.b.31620

105. Cheng L, Weir MD, Xu HH, Kraigsley AM, Lin NJ, Lin-Gibson $S$ et al. Antibacterial and physical properties of calcium-phosphate and calcium-fluoride nanocomposites with chlorhexidine. Dent Mater. 2012;28(5):573-83. https://doi.org/10.1016/j.dental.2012.01.006 